\title{
Different distributions of contrastive vowel nasalization in Basque
}

\author{
Ander Egurtzegi \\ University of the Basque Country \\ ander.egurtzegi@ehu.eus
}

\begin{abstract}
Submitted: 30/07/2014. Accepted: 14/11/2014. Av ailable on line: 01/12/2015
Citation / Cómo citar este artículo: Egurtzegi, A. Different distributions of contrastive vowel nasalization in Basque. Loquens, 2(1), e017. doi: http://dx.doi.org/10.3989/loquens.2015.017
\end{abstract}

\begin{abstract}
Contrastive vowel nasalization is usually a consequence of the reinterpretation of the phonetic nasalization of a vowel due to coarticulation with an adjacent nasal consonant as originating in the vowel itself. Basque developed contrastive vowel nasalization after the loss of the nasalized laryngeal / $\tilde{\mathrm{h}} /$ (from older intervocalic $* n$ ). This loss did not occur under the same circumstances in all dialects, and thus yielded different distributions of contrastive nasalization. This paper discusses the development of two different patterns of contrastive vowel nasalization, namely those of Zuberoan and Roncalese dialects.

While modern Zuberoan shows contrastive vowel nasalization only in the last syllable, the now extinct Roncalese dialect had phonologically nasalized vowels in any syllable of the word. In addition, these two dialects possessed different nasalized vowel inventories. Other Basque dialects with attested contrastive vowel nasalization, such as Old Bizkaian, are discussed as well.

Although the presence of contrastive vowel nasalization in Basque is known in the literature (see Hualde, 1993, and Michelena, 1977/2011, for Zuberoan; and Michelena, 1954/2011, for Roncalese), this paper presents new analyses of vowel nasalization of two neighboring dialects of Basque, Zuberoan and Roncalese.
\end{abstract}

Keywords: nasalization; vowel inventories; historical phonology; Basque.

RESUMEN: Diferentes distribuciones de la nasalización vocálica contrastiva en vasco.- La nasalización vocálica contrastiva es habitualmente consecuencia de la reinterpretación de la nasalización fonética de una vocal debida a la coarticulación con una consonante nasal adyacente como si esta se originase en la propia vocal. El euskera desarrolló nasalización vocálica contrastiva tras la pérdida de la laringal nasalizada / $\widetilde{h} /\left(\right.$ de antigua ${ }^{*} n$ intervocálica). Esta pérdida no ocurrió en los mismos contextos en todos los dialectos y, por lo tanto, dio lugar a diferentes distribuciones de la nasalización contrastiva. Este artículo analiza el desarrollo de los patrones de nasalización vocálica contrastiva en los dialectos vascos suletino y roncalés.

Mientras que el suletino moderno muestra nasalización contrastiva solo en la última sílaba, el ahora extinto dialecto roncalés llegó a poseer vocales fonológicamente nasalizadas en cualquier sílaba de la palabra. Estos dos dialectos poseían, además, distintos inventarios de vocales nasalizadas. También se analizan otros dialectos vascos con nasalización vocálica atestiguada, como el vizcaíno antiguo.

A pesar de que la presencia de nasalización vocálica contrastiva en euskera es conocida en la bibliografía (v. Hualde, 1993, y Michelena, 1977/2011, para el suletino; y Michelena, 1954/2011, para el roncalés), este trabajo presenta nuevos análisis de la nasalización en suletino y roncalés, dos dialectos vascos vecinos.

Palabras clave: nasalización; inventarios vocálicos; fonología diacrónica; euskera.

\section{INTRODUCCIÓN}

Nasalization is one of the most widespread (non-basic) vocalic features in the world's languages, together with contrastive vowel length (Ladefoged \& Maddieson, 1996, p. 298). In the UPSID database 71 out of 317 languages (22.4\%) show this feature (Maddieson, 1984, p. 130).

Most authors (first Larrasquet, 1939, and then echoed by Michelena, 1977/2011; Hualde, 1993, 2003; or Zuazo, 2008, p. 46) describe vowels surrounding nasal 
consonants as nasalized in Basque. Examples of noncontrastive phonetic nasalization include any vowel in contact with a nasal or nasalized consonant, such as the vowels in the Zuberoan words khatiña $/ \mathrm{k}^{\mathrm{h}} \mathrm{a}$.'ti.na/ [ $\mathrm{k}^{\mathrm{h}} \mathrm{a}$.

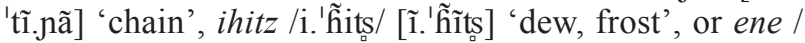
'e.ne/ ['ẽ.nẽ] 'mine'. In addition, contrastive vowel nasalization has been described in the literature for some Basque dialects, most notably Zuberoan (see Hualde, 1993, 2003; Michelena, 1977/2011). In this paper, I build on previous analyses and propose a more detailed description, which involves a new, more restrictive analysis including a smaller nasalized vowel inventory in the case of Zuberoan and the restriction of the nasalization contrast to the stressed syllable in both Zuberoan and Roncalese.

This initial section serves as an introduction. Section 2 discusses the unrestricted distribution of contrastive vowel nasalization in Roncalese and Old Bizkaian (2.1) and the restricted distribution found in Zuberoan (2.2), then their historical development and a comparison between them (2.3), as well as briefly mentioning the historical presence of contrastive nasalization in other Basque dialects (2.4). Finally, section 3 offers conclusions on the previously discussed sound patterns.

Contrastive vowel nasalization is usually a consequence of the reinterpretation of the phonetic nasalization of a vowel due to coarticulation with an adjacent nasal consonant as originating in the vowel itself (see Beddor, 2009; Hajek, 1993; Ohala, 1993, pp. 247-248). In languages which previously lacked contrastive vowel nasalization, the development of an opposition between oral and nasalized vowels is usually associated with the loss of a nasal consonant (see Blevins, 2004, p. 202; Hajek, 1997; Ohala 1981, p. 186, 1989). Thus, nasalized vowels are not "created" after the loss of a nasal consonant, given that they were already nasalized prior to the consonant drop, at least phonetically (see Ohala, 1993 , p. 248). It is typically only after the loss of the nasal consonant that they become contrastive segments and an opposition between oral and nasalized vowels arises.

\section{DISTRIBUTIONS OF CONTRASTIVE VOWEL NASALIZATION IN BASQUE}

In Basque, contrastive vowel nasalization arised in $* \mathrm{VnV}$ sequences. First, all instances of intervocalic /n/ systematically became a nasalized aspirate $/ \tilde{\mathrm{h}} /$ around the beginning of the Middle Ages (see Egurtzegi, 2014, section 4.2.3; Egurtzegi, sub.; Igartua, 2008). ${ }^{1}$ Later, after the loss of the aspirates $/ \mathrm{h} /$ and $/ \tilde{\mathrm{h}} /$, vowels surrounding the nasalized aspirate $/ \tilde{\mathrm{h}} /$ became contrastively nasalized. Aspirated segments were lost in two ways in the different Basque dialects (Egurtzegi, 2014, section 4.3): they were either dropped after the second (stressed) syllable - as in the continental dialects Lapurdian, Low Navarrese and Zuberoan - or they were lost altogetheras ultimately happened in the other dialects. Lastly, / $/ \tilde{\mathrm{h}} /$ was deprived of its nasalization and merged with $/ \mathrm{h} / \mathrm{in}$ Lapurdian and Low Navarrese. Thus, nasalized $/ \tilde{\mathrm{h}} /$ is only preserved in modern Zuberoan and only in the second syllable of the word. The domain of $/ \tilde{\mathrm{h}} /$ loss and $/ \tilde{\mathrm{h}} /$ retention is depicted in Figure 1: / $\tilde{\mathrm{h}} /$ is maintained in the head syllable of a word-initial iambic foot. Table 1 shows examples of the evolution of nasalized $/ \tilde{\mathrm{h}} /$ in the inherited lexicon and Latin loanwords and Table 2 shows examples of retention of $/ \mathrm{h} /$ in the first two syllables:

Figure 1. Domain-dependent loss (and retention) of $/ \tilde{\mathrm{h}} /$ in Zuberoan.

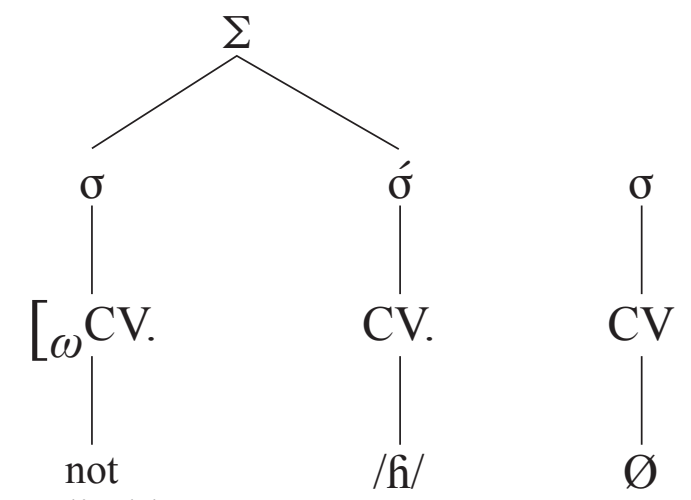

applicable

Table 1. Intervocalic $/ \mathrm{n} / \mathrm{>} / \tilde{\mathrm{h}} /$ in modern Zuberoan.

\begin{tabular}{|c|c|c|c|}
\hline Rec./Lat. & Zuberoan & Trans. & Gloss \\
\hline *anari & ahái & /a.'T̃ai/ & 'ram' \\
\hline *ini & ihi & /'i.ñì/ & 'reed' \\
\hline ANǍTEM & aháte & /a.'โ̃a.te/ & 'duck' \\
\hline HONŌREM & uhúe & /u.'ก̃u.e/ & 'honor' \\
\hline
\end{tabular}

Table 2. Retention of $/ \mathrm{h} /$ in modern Zuberoan.

\begin{tabular}{cccc}
\hline Rec. & Zuberoan & Trans. & Gloss \\
\hline *hirur & hiu & /hju/ & 'three' \\
*haur & hau & /hau/ & 'this' \\
*alhaba & alhaba & /al.'ha.ba/ & 'daughter' \\
*zahar & zahar & / sa.'har/ & 'old' \\
\hline
\end{tabular}

Given that all laryngeals were dropped altogether from the 11th to the 14th century in the central and western dialects (in Michelena, 1977/2011, p. 169; Salaberri,

\footnotetext{
${ }^{1}$ Aquitanian roots such as seni-(Gorrochategui, 1984) still show the intervocalic nasal stop absent in its more recent forms, cf. Archaic Bizkaian sẽ̃ (> modern sein) 'boy' and Lapurdean and Low Navarrese sehi 'servant'.
} 
2013; see Egurtzegi, 2014, section 4.3.1), these varieties possibly possessed nasalized vowels in any syllable. On the other hand, eastern dialects only lost aspirates from the second syllable on (see Egurtzegi, 2014, section 4.3.2), so that vowel nasalization could only develop within that domain in that area.

As a consequence, two different patterns of nasalization evolved independently in different Basque dialects depending on the context where laryngeals were lost. While Roncalese lost laryngeals altogether, the neighboring Zuberoan dialect maintained both laryngeals $/ \mathrm{h} /$ and nasalized $/ \tilde{\mathrm{h}} /$, the former in the first two syllables of the word (Table 2) and the latter in the second syllable only (Table 1). Thus, Roncalese vowels can contrast in nasality in any part of the word and appear in both monosyllabic and disyllabic/polysyllabic words, while the same contrast is only found in the stressed syllable of oxytonic disyllabic/polysyllabic words in Zuberoan, and it is thus absent from word-initial syllables (see Hualde, 2003, p. 31 ). Each distribution is discussed in turn in the following sections.

\subsection{Unrestricted distribution: Roncalese and Archaic/Old Bizkaian}

The first distribution of contrastively nasalized vowels found in Basque is unrestricted. In dialects such as Roncalese (or Old Bizkaian), contrastive nasalization can appear in any syllable of the word. Nevertheless, in Roncalese (but not in Bizkaian), contrastive vowel nasalization is limited to the stressed syllable. In Roncalese, unmarked stress falls in the penultimate and marked stress falls in the last syllable of the stem. In Old Bizkaian, synchronically, nasal vowels are restricted to appear within the domain of a foot in the absence of an intervocalic syllable onset. This distribution has been found in dialects where all laryngeals were lost before the loss of the nasality in $/ \tilde{\mathrm{h}} /$, giving rise to nasalized hiatuses that became nasalized diphthongs if the last vowel was high-i.e., $/ \mathrm{VnV} />/ \mathrm{V} \tilde{\mathrm{VV}} />[\tilde{\mathrm{V}} \tilde{\mathrm{V}} \tilde{\mathrm{V}}]>/ \tilde{\mathrm{V}} . \tilde{\mathrm{V}} /$ $(>/ \tilde{\mathrm{V}} \tilde{\mathrm{V}} /)$. Examples of this sequence of processes and the subsequent distribution are found in Roncalese or Archaic and Old Bizkaian dialects. While Roncalese maintained this opposition until its disappearance in the 20th century, Bizkaian merged nasalized vowels and diphthongs with their oral counterparts around the 17 th century, although potential instances of vowel nasalization can be found until the second half of the 18th century (see Ulibarri, 2015).

Examples of Roncalese nasalized vowels in Table 3 are taken from Michelena (1953/2011, 1954/2011) and those from Archaic and Old Bizkaian in Table 4 are from Ulibarri (2015) and Lakarra (1996):
Table 3. Contrastively nasalized vowels and diphthongs in Roncalese.

\begin{tabular}{|c|c|c|c|}
\hline Roncalese & Trans. & Std. Basque & Gloss \\
\hline$\tilde{a} r$ & /ãr/ & har & 'worm' \\
\hline$\tilde{o} l$ & /õ1/ & ohol & 'board' \\
\hline (i) $\tilde{\imath} z e$ & /'̃̃.se/ & ehiza & 'hunt' \\
\hline ãutzto & /'ãĩns.to/ & aizto & 'knife' \\
\hline ardãu & /ar.'dã̃uِ// & ardo & 'wine' \\
\hline$\tilde{e} \tilde{u} r$ & /ẽũ̃r/ & inor & 'somebody' \\
\hline$s \tilde{u}, s \tilde{\imath}$ & /sũu $/, /$ s $\tilde{\mathbf{1}} /$ & suhi & 'son-in-law' \\
\hline
\end{tabular}

Table 4. Contrastively nasalized vowels and diphthongs in Archaic and Old Bizkaian. ${ }^{2}$

\begin{tabular}{|c|c|c|c|}
\hline $\begin{array}{c}\text { Archaic/Old } \\
\text { Bizkaian }\end{array}$ & Trans. & Std. Basque & Gloss \\
\hline burdĩa & /bur.dĩ.ã/ & burdina & 'iron' \\
\hline sardĩa & / sua.dĩ.ã/ & sardina & 'sardine' \\
\hline$m \tilde{\imath}$ & $/ \mathrm{mi} /$ & mihi & 'tongue' \\
\hline arrã̃ & /a.rã $\tilde{n} /$ & arrain & 'fish' \\
\hline$s \tilde{e} \tilde{\imath}$ & /șẽ $\tilde{1} /$ & sein & ‘boy’ \\
\hline$\tilde{o} \tilde{\imath}$ & /õ $\tilde{1} /$ & oin & 'foot' \\
\hline
\end{tabular}

\subsubsection{Development of the Roncalese system}

After the unconditioned loss of all aspirates in Roncalese, vowels that were phonetically nasalized due to an adjacent $/ \tilde{\mathrm{h}} /$ lost the segmental source of their phonetic nasalization and became phonologically nasalized. Thus, $/ \tilde{\mathrm{h}} /$ loss produced contrastively nasalized vowel encounters in any part of the word in Roncalese, as well as in Archaic Bizkaian. Then, vowel clusters were simplified

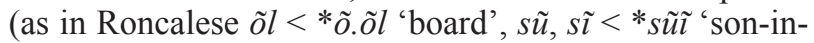
law', or Old Bizkaian $m \tilde{\imath}<* m \tilde{\imath} . \tilde{l}$ 'tongue') and falling vocalic sequences were diphthongized (in Roncalese ardãu

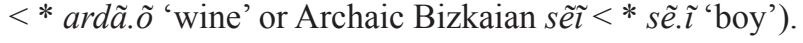

There is one notorious difference between the nasalized vowel distribution found in older stages of Bizkaian and that found in Roncalese: while contrastively nasalized vowels could appear anywhere in the word in Bizkaian, they were restricted to the stressed syllable in Roncalese (as they are in Zuberoan, see 2.2). Crucially, Bizkaian is the only dialect to maintain phrase-level accentuation (as reconstructed for Common Basque; see Egurtzegi \& Elordieta, 2015), in contrast to the word-level accentuation found in Roncalese, where unmarked stress falls in the penultimate syllable of the stem.

${ }^{2}$ No stress diacritic is used in these transcriptions due to the lack of word-level stress in Old Bizkaian. 
In Roncalese, as well as in Zuberoan, the older system of peninitial stress - which developed from a common phrase-level stress in the central and eastern Basque dialects - shifted towards a system with unmarked paroxitonic stress and marked stress in the last syllable (see Egurtzegi, 2014, section 3.4.3; Egurtzegi \& Elordieta, 2015; Michelena, 1977/2011, pp. 344-345). The set of accentually marked words in the innovative accentual systems in these dialects is the consequence of the heterosyllabic vowel cluster simplification and diphthongization mentioned above.

In a few cases, both stress and contrastive nasalization have shifted from the marked last syllable to the unmarked penultimate, regularizing the stress in these words but maintaining nasalization in the stressed position. Such are the cases of Roncalese ấria $<*$ arĩ $\tilde{a}<*$ arẽ. $\tilde{a}<*$ are $\tilde{h} a$ $<$ Latin ARĒNA 'sand', and gấzta $<*$ gaztấ $<*$ gaztã. a $<$

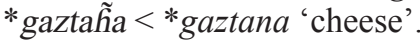

\subsection{Restricted distribution: Zuberoan}

Modern Zuberoan shows contrastive nasalization only in stressed word-final position.

Given that modern Zuberoan maintains both laryngeals (as observed by Lafon, 1958/1999, and phonologically analyzed by Hualde, 1993, and Egurtzegi, sub.) in the first two syllables of the word (see ahái /a.'T̃ai/ 'ram', ahántzi /a.'T̃an.tsi// 'forget', aháte /a.'T̃a.te/ 'duck̂', hoi / hoi/ 'that', haiña /'hai.na/ standard harea 'sand', etc.), this dialect did not develop contrastive vowel nasalization in contexts where $/ \tilde{\mathrm{h}} /$ was maintained, namely before the onset of the second syllable. On the other hand, Zuberoan-as well as the other eastern dialects (see Egurtzegi, 2014, section 4.3.2; Egurtzegi \& Elordieta, 2015)—lost all laryngeals after the second syllable (see Michelena, $1950 / 2011$, pp. $18-19 ; 1977 / 2011$, p. 177), i.e., in the onset of $\sigma_{22}$. As a consequence of the domain-dependent loss of $/ \widetilde{\mathrm{h}} /$, nasalized vowels may be found in this particular domain only, thus giving rise to a restricted distribution of the vowel nasalization contrast.

In modern Zuberoan, stressed word-final vowels can be contrastively nasalized (see Hualde, 1993; 2003, p. 31). Contrastively nasalized vowels are the result of the loss of intervocalic $/-\tilde{\mathrm{h}}-/$ from the third syllable of the word. Due to the very restricted environment where these segments developed, inherited words that have nasalized vowels are very scarce in this dialect. Table 5 offers examples of contrastively nasalized vowels in inherited words while Table 6 shows examples of the development of nasalized vowels in Latin loanwords. In these cases, contrastively nasalized vowels have developed within the Basque language. Examples in Tables 5 and 6 are from Larrasquet (1939).
Table 5. Contrastively nasalized vowels in the Zuberoan inherited lexicon.

\begin{tabular}{|c|c|c|c|}
\hline Zuberoan & Trans. & Std. Bsq. & Gloss \\
\hline $\operatorname{ardú́}$ & /ar.'dũ// & ardo & 'wine' \\
\hline 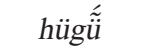 & /hy.'gỹ/ & higuin & 'repugnance' \\
\hline gorriû́ & /go.'rjũ/ & - & $\begin{array}{l}\text { 'reddish } \\
\text { mushroom' }\end{array}$ \\
\hline hazkû́ & /haș.'kũ/ & $a z k o(i) n$ & 'badger' \\
\hline Xiberû́ & /si.be.'rũ/ & Zuberoa & '(region)' \\
\hline
\end{tabular}

Table 6. Contrastively nasalized vowels in Latin loanwords.

\begin{tabular}{cccc}
\hline Latin $^{3}$ & Zuberoan & Trans. & Gloss \\
\hline $\begin{array}{c}\text { BIMUS }+ \\
\text {-ANA }\end{array}$ & bigã́ & /bi.'gã// & $\begin{array}{c}\text { '2-year-old } \\
\text { heifer' }\end{array}$ \\
LEŌNE(M) & lehṹ & /le.'hũ// & 'lion' \\
ORGANA & orgã̃ & /or.'gãa/ & 'cart' \\
\hline
\end{tabular}

However, recent borrowings have increased the number of words with phonologically nasalized vowels. Examples in Table 7 show contrastively nasalized vowels in loanwords from Bearnese Gascon. In contrast to the older Latin loanwords, Bearnese borrowings possessed word-final contrastively nasalized vowels prior to their introduction to Zuberoan Basque. Phonologically nasalized vowels introduced with Bearnese Gascon loanwords

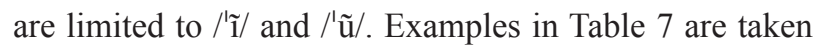
from Larrasquet (1939).

Table 7. Contrastively nasalized vowels in Bearnese Gascon loanwords.

\begin{tabular}{|c|c|c|c|}
\hline Bearnese & Zuberoan & Trans. & Gloss \\
\hline /mede'sĩ)/ & bedezĩ́ & /be.de.'Zू̃ / & 'physician' \\
\hline /ku'z̃̃ / & kosĩ́ & /ko.'Zูĩ/ & 'cousin' \\
\hline$/(\tilde{1} /$ & lĩ & $/$ /1̃ $/$ & 'linen' \\
\hline /ara'zũ/ & arrazṹ & /a.ra.'zũ / & 'reason' \\
\hline /pi'zũu/ & pijû́ & /pi.'3ũu/ & 'pidgeon' \\
\hline$/ \mathrm{sa}^{\prime} \mathrm{z} \tilde{\mathrm{u}} /$ & sasû́ & /șa.'zũu/ & 'season' \\
\hline
\end{tabular}

These borrowings drastically increased the frequency of $/ \tilde{\mathbf{u}} /$ and $/ \tilde{\mathbf{i}} /$ in Zuberoan Basque. The high frequency of these vowels contrasts with the scarcity of $/ \tilde{a} /$ and, especially, $/ \tilde{y} /$, as well as the lack of phonologically nasalized mid vowels.

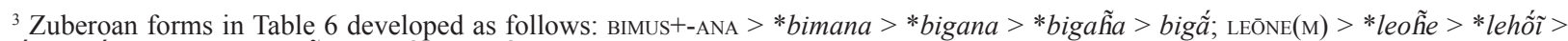

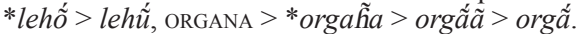

4 It is not clear whether this word is a compound of Basque biga 'two' or a Latin loan from bimus-ana $>*$ bimana. Michelena proposed the former first and the latter later (see Arbelaiz, 1978). A derivation from the Latin form meets the problem of $/ \mathrm{m} /(>/ \mathrm{b} /)>/ \mathrm{g} /, \mathrm{a}$ change which is far from common.
} 


\subsubsection{Development of the Zuberoan system}

In older stages of the eastern Basque dialects, $/ \tilde{\mathrm{h}} /$ loss occurred after the shift from a phrase-level pitch accent system to word-level peninitial syllable stress (Table 8.ii; see Egurtzegi \& Elordieta, 2015). With the generalization of the innovative accentual system, $/ \tilde{\mathrm{h}} /$ (as well as $/ \mathrm{h} /$ ) dropped only after the second syllable of the word in the varieties that would give rise to Zuberoan as well as Lapurdean and Lower Navarrese (Table 8.iii).

Most native Basque words at this stage were not longer than three syllables. As a consequence, the loss of laryngeals can be described as occurring in the post-tonic third syllable when word-stress fell on the second syllable. This loss produced contrastive nasalization, presumably on both vowels surrounding the lost laryngeal. In most cases, nasalized vowels were in the second and the third (and last) syllables of the word.

Stress was later reanalyzed as occurring on the penultimate syllable instead of the second syllable in Zuberoan (probably in trisyllabic words; Michelena, 1977/2011, pp. 344-345; see Egurtzegi, 2014, section 3.4.3; Egurtzegi \& Elordieta, 2015; see Table 8.iv). With the development of this new stress system, nasalized vowels that were located in the stressed penultimate syllable of the word were prominent and may have been regarded as the only source of phonological nasalization, which extended to the next vowel phonetically. This reanalysis produced a constraint of contrastive vowel nasalization being effective only in the stressed syllable, which was the penultimate (Table 8.v). This constraint of nasalized vowels only found in stressed syllables finds a parallel in Gascon (see Sampson, 1999, p. 154), the Romance language in contact with Zuberoan, which, interestingly, also possesses a stress system with only paroxytonic and oxytonic words.

Later, a marked stress pattern of oxytones was created after former examples of contrastively nasalized vowels in the stressed syllable of paroxytonic words underwent several processes affecting hiatuses. Such processes include diphthongization, blending of vowel clusters involving back vowels and simplification of sequences of similar vowels (Table 8.vi-a). Examples of vowel blending include ardú /

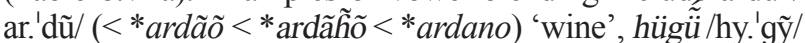
$(<*$ higũ $<*$ igu $\tilde{\text { hi }}<*$ e/iguni) 'repugnance', and simplifications include gaznã /gas.'nã/ $(<*$ gaznãã $<*$ gaztaก̃a $<$ * gaztana) 'cheese'. The word ardú 'wine' also shows the regular raising of nasalized /õ/ that occurred after the blending of vowel clusters involving the mid back vowel (Table 8.vii). Hiatuses were diphthongized or simplified in all cases except when the first and stressed vowel of the cluster was /'ẽ/ or $/ \tilde{1} /$, which were both maintained as / / $/$ / (Table 8.vi-b). Later, the insertion of a nasal stop after $/ \tilde{1} /$ dephonologized the nasality in paroxytones (Table 8.viii). The insertion of a palatalized nasal stop occurred after both $/ \tilde{\mathbf{1}} /$ and the semivowel
1ิ/. Examples of nasal insertion include khatiña (cf. older Zuberoan khatĩa) 'chain', lozebiña (cf. older Zuberoan lozebĩa) 'wasp' or erregiña (cf. sixteenth-century Alavese erregĩa) 'Queen', or diphthongs such as arrain (cf. Old Bizkaian arrã̃) 'fish'. These processes gave rise to the set of marked oxytonic words found in Zuberoan Basque as well as creating the modern distribution of nasalized vowels in this dialect, i.e., only in word-final stressed position.

In addition, two processes of regular vowel raising reduced the inventory of contrastively nasalized vowels to $/ \tilde{1}$, $\tilde{y}, \tilde{a}, \tilde{u} /$, instead of the Zuberoan oral vowel system /i, y, e, $\mathrm{a}, \mathrm{o}, \mathrm{u} / .^{5}$ This is the historical consequence of /ẽ/ being raised to / $\tilde{1} /$ when in a hiatus (cf. Latin CATĒNA $>* k a t e \tilde{h} a>$ *katếã $>$ katĩ́a $>$ katíña 'chain' and Latin ARĒNA $>*$ are $\tilde{a} a>$ *harễã > *harĩ́a > haríña 'sand', see Egurtzegi, 2013, and Michelena, 1977/2011, pp. 89-90, on these processes) and

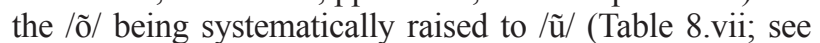
Egurtzegi, 2014, section 7.2.1; and Michelena, 1977/2011, p. 38), as in $\operatorname{ard} \tilde{u}<*$ ardõ 'wine'.

In addition, modern Zuberoan lacks nasalized diphthongs due to the simplification of diphthongs involving a back (semi)vowel (cf. Roncalese ardãu vs. Zube-

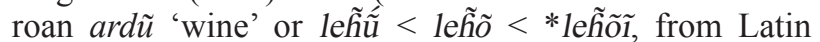
LEŌNE(M) 'lion') and the systematic restitution of $/ \mathrm{n} /$ after the nasalized front glide $/ 1 /$ mentioned above (cf. Roncalese arrã̃̃ vs. Zuberoan arrain 'fish').

The sequence of processes that gave rise to the Zuberoan system of contrastively nasalized vowels is depicted under Table 8.

Table 8. Processes involved in the development of Zuberoan nasalized vowel distribution.

\begin{tabular}{|c|c|c|c|}
\hline & Process & Oxytones & Paroxytones \\
\hline- & Reconstructed form & $\begin{array}{l}\text { *ardano } \\
\text { 'wine' }\end{array}$ & $\begin{array}{l}\text { Lat. ARĒNA } \\
\text { 'sand' }\end{array}$ \\
\hline $\mathrm{i}$ & $/ \mathrm{n} />/ \tilde{\mathrm{h}} / / \mathrm{V}_{-} \mathrm{V}$ & 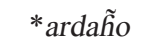 & *are $\tilde{\text { a }}$ \\
\hline ii & Peninitial stress & 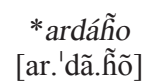 & 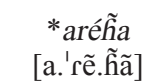 \\
\hline iii-a & Metathesis of $/ \tilde{\mathrm{h}} /$ in $\sigma_{>2}$ & - & *haré̃ã \\
\hline iii-b & Deletion of $/ \tilde{\mathrm{h}} /$ in $\sigma_{>2}$ & *ardã́õ & - \\
\hline iv & $\begin{array}{c}{[+2]>[-2] \text { stress }} \\
\text { reanalysis }\end{array}$ & *ardấõ & *harếã \\
\hline $\mathrm{v}$ & $\begin{array}{l}\text { Denasalization of } \\
\text { unstressed syllables }\end{array}$ & *ardấo & *harếa \\
\hline vi-a & $\begin{array}{l}\text { VV blending involving } \\
\text { back vowels }\end{array}$ & *ardố & - \\
\hline vi-b & Raising of /e, ẽ//_V & - & *haría \\
\hline vii & Raising of / $/ \tilde{\text { o }}$ & $\operatorname{ardú}$ & - \\
\hline viii & Insertion of $/ \mathrm{n} / \operatorname{after} \tilde{\mathrm{i}}, \tilde{\mathrm{I}}$ & - & hariña \\
\hline
\end{tabular}

\footnotetext{
${ }^{5}$ Zuberoan is the only Basque dialect which has developed a sixth vowel quality in addition to the common five vowel inventory /i, e, a, $\mathrm{o}, \mathrm{u} /$, namely the high front rounded vowel /y/.

${ }^{6}$ The shift in this step may not be apparent, but it implies the relocation of the stress from the Central to the Eastern type (see Egurtzegi, 2014,

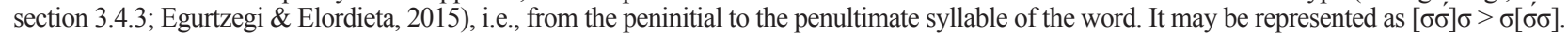


As already explained, due to the domain-restricted origins of the Zuberoan contrastive vowel nasalization, there are no contrastively nasalized vowels in the first syllable of inherited words. This is a consequence of the dropped $/ \tilde{\mathrm{h}} /$ being located from the third syllable onward. Nasalized aspirates in the second syllable were maintained in Zuberoan (see *ini $>$ i $\tilde{i} i$ 'reed'). Thus, nasalized vowels did not develop before the second syllable of native Zuberoan words. This restriction distinguishes Zuberoan from Archaic/Old Bizkaian and Roncalese.

As mentioned in section 2.2, stressed word-final nasalized vowels were also incorporated into Zuberoan in borrowings from Bearnese Gascon. Thus, the scarce nasalized vowels in word-initial syllables in modern Zuberoan are found in monosyllables with nasalized vowels borrowed from Gascon, such as $f \tilde{l}$ 'fine, prudent' or $l \tilde{l}$ 'linen'. Native Zuberoan words would not result in monosyllables with nasalized vowels, given that the loss of $/ \tilde{\mathrm{h}} /$ only occurred from the third syllable onward.

\subsection{Differences among the distributions}

There are four main differences between the distribution of nasalized vowels in Archaic/Old Bizkaian and Roncalese and that found in Zuberoan. First, the nasalized vowel inventories are different: / $\tilde{1}, \tilde{e}, \tilde{a}, \tilde{o}, \tilde{\mathrm{u}} /$ in Ar-

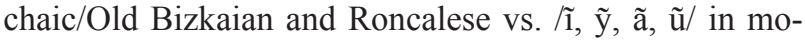
dern Zuberoan. Second, in contrast to the other dialects, there are no nasalized diphthongs in Zuberoan. Third, nasalized vowels are absent from the first syllable of the word in Zuberoan, but first syllable nasalized vowels are common in Roncalese and Archaic/Old Bizkaian. Fourth, the opposition is restricted to the stressed syllable of oxytones in Zuberoan, while in Archaic/Old Bizkaian it does not need to be so.

Nevertheless, the restriction of nasalized vowels to the stressed syllable groups together Zuberoan and Roncalese (instead of Archaic/Old Bizkaian and Roncalese, as in the previous cases), being the biggest difference between the distribution of nasalized vowels found in Archaic/Old Bizkaian and that of Roncalese. This may be due to the fact that Zuberoan and Roncalese share a very similar accentual system with unmarked stress in the penultimate and marked stress in the last syllable of the word or stem (in Zuberoan and Roncalese, respectively), in contrast to the much more conservative phrase-level system found in Bizkaian (see Egurtzegi, 2014, Chapter 3; Egurtzegi \& Elordieta, 2015, for the evolution of the Basque accentual systems).

In addition, modern Zuberoan is highly skewed regarding the frequency of the different nasalized vowels.
Firstly, Zuberoan lacks nasalized mid vowels after their systematic raising, as discussed in section 2.2.1. Secondly, due to the massive introduction of Bearnese loanwords involving / $\tilde{\mathbf{1}} /$ and, especially, / $\tilde{\mathbf{u}} /$ (Table 7 ), the presence of these nasalized vowels has increased considerably over time. Lastly, due to the very restrictive conditions for language-internal development of nasalized vowels and no nasalized vowel other than $/ \tilde{\mathbf{i}} /$ and $/ \tilde{\mathrm{u}} /$ being introduced by borrowing, the presence of $/ \tilde{a} /$ and $/ \tilde{y} /$ is limited to a couple of items, namely two potential Latin loanwords (bigá '2-year-old heifer' and orgấ 'cart' in Table 6) and a single seemingly native word (hügü̈ 'repugnance').

\subsection{Contrastive vowel nasalization in other Basque dialects}

In addition to the discussed dialects, the oldest written documents (excluding Aquitanian; see Gorrochategui, 1984) show contrastive vowel nasalization in other varieties of Basque: the brief word-list compiled by the twelfth-century pilgrim Aymeric Picaud in his Guide for the Traveler (Iter pro peregrinis ad Compostellam, book $\mathrm{V}$ of the Codex Calixtinus, written around 1140) already included items with a nasalized vowel such as <ardum $>$ 'wine' and <araign> 'fish' (in Michelena, 1964/2011, pp. 51-53; see also Trask, 1997, 44-45). ${ }^{7}$ This word list is assumed to be written in a High Navarrese variety of the language (see Martínez-Areta, 2009, p. 76; Michelena, 1964/2011, p. 63). The name [Eneco] Arçaia (cf. artzaina 'the shepherd'), attested in the 13th century (Michelena, 1964/2011, p. 37), reflects another potential instance of contrastive vowel nasalization in Navarre.

Potential evidence of phonologically nasalized vowels in Lapurdian is found in Vocabula Biscaica, the second word-list of the Glossaria duo Vasco-Islandica (Deen, 1937/1991, which includes three seventeenth-century glossaries: the two included in Glossarium Prius [Vocabula Gallica] et Glossarium Alterum [Vocabula Biscaica alterius auctoris], and Egilsson's Tertii cuiusdam glossarii quae reliqua sunt). This glossary lists Basque words as elicited by an Icelander who was probably involved in trade with Basque fishermen. The variety which the fishermen spoke is assumed to be Lapurdian (see Deen, 1937/1991; Hualde, 1984/1991, 1991), and the relations took place during the 16 th and 17 th centuries.

Among many other words, the especially interesting <sagarduna> 'cider' (cf. Standard Basque sagardoa) appears two times in the glossary (Deen, 1937/1991, pp. 75 and 82 ), and in both cases shows an unexpected graphic $<\mathrm{n}>{ }^{8}$ This grapheme may be much better understood if attributed to a nasal vowel (cf. Zuberoan ardî́ 'wine'), trans-

\footnotetext{
${ }^{7}$ The final $<-\mathrm{m}>$ in ardum is not due to Latin accusative declension, but rather is a way of indicating a preceding nasalized vowel, as was first pointed out by Bonaparte in a letter to Webster (Webster, 1881, p. 125; cf. Michelena, 1964/2011, p. 52). The final <-gn> in araign may also stand for the nasalization in the preceding vowel.

${ }^{8}$ Although $-n$ is maintained in the combination form ardan- used only in compounds (as in ardandegi 'winery'), the $<\mathrm{n}>$ in $<$ sagarduna $>$ does not seem analogical, given that it follows a back vowel that is only maintained in full forms: compare the dialectal variants ardao, ardo, ardu, etc., to the common combination form ardan-.
} 
cribed as an obstruent by a non-speaker of the language. Although such vocabularies are filled with transcription errors, an $<\mathrm{n}>$ showing up where vowel nasality is expected in other dialects seems out of the reach of the power of chance, even more given that this word appears twice in the document. Thus, it may have been the case that a foreigner wrote down something that no native speaker felt the need to, and at least some Lapurdian speakers had some vestiges of vowel nasality until the 17th century.

In addition, the General Basque Dictionary (Michelena \& Sarasola, 1987-2005) mentions that the word for 'Queen' (Standard Basque erregina) is attested without an orthographic nasal <erregia $>$ in the Alavese author Lazarraga, the High Navarrese author Beriain, in a High Navarrese Salve Regina from the end of the 16th century (which probably followed the unrestricted distribution in section 2.1) as well as in certain Lapurdian correspondence from the same period, which probably implies the presence of a nasalized vowel on it, given that the modern form of this word is erregina in all Basque dialects.

All Basque varieties - with the exception of Zuberoan - are expected to have possessed an inventory of five nasalized vowels /ĩ, ẽ, ã, õ, ũ/, and a distribution of vowel nasality not necessarily limited to the stressed syllable. However, a domain-dependent pattern is expected in any other dialect which maintained aspirates in the first two syllables of the word, namely in Lapurdian and Low Navarrese. Nevertheless, nasalized vowels do not need to be stressed in these dialects, given that they do not share the Eastern stress system present in Zuberoan and Roncalese, in which stress always falls in one of the last two syllables. It was only in varieties with the Eastern stress system that all nasalized vowels were stressed.

In the 20th century, we only find oppositions between oral and nasalized vowels in Zuberoan and Roncalese dialects. Contact between Zuberoan and Bearnese Gascon may have helped preserve the distinction until recent times.

\section{CONCLUSIONS}

Different Basque dialects have developed different distributions of contrastive vowel nasalization. This paper has discussed the distribution of contrastive vowel nasalization in Roncalese and Archaic/Old Bizkaian in contrast to the distribution found in Zuberoan Basque.

Nasalized vowels arose after intervocalic *n systematically became a nasalized aspirate $/ \tilde{\mathrm{h}} /$, which was subsequently lost under different conditions in different dialects. In most dialects, five nasalized vowels /r, ẽ, ã, õ, ũ/, as well as nasalized diphthongs, developed in any given syllable of the word after aspirates including $/ \tilde{\mathrm{h}} /$ merged with zeroi.e., they were lost altogether. This is the case of both western sixteenth-century Bizkaian and eastern Roncalese dialects, as well as (potentially) all dialects in between. Wherever aspirates were lost after the second syllable, as in the case of Lapurdian and Low Navarrese, contrastive vowel nasalization developed in a domain-dependent way, in complementary distribution with the presence of $/ \tilde{\mathrm{h}} /$ and /h/ - i.e., from the second syllable — but involving the same nasalized vowel inventory present in western (and central) Basque dialects. I have proposed that the biggest difference between the distributions found in Old Bizkaian and Roncalese lies in the restriction of contrastive nasalization to stressed vowels, which has been proposed to be a consequence of the Eastern stress system found in both Roncalese and Zuberoan, which also has nasalized vowels only in stressed syllables (see Hualde, 1993).

The case of Zuberoan is more complex. I propose that the combination of the domain-dependent distribution of continental dialects (Lapurdian, Low Navarrese and $\mathrm{Zu}-$ beroan) and the innovative Eastern stress system found in Zuberoan and Roncalese yielded a pattern where contrastively nasalized vowels are limited to the stressed last syllable of the word. The constraint of contrastive vowel nasalization being effective only in stressed syllables finds a parallel in Bearnese Gascon, the Romance language in contact with Zuberoan.

In addition, the inventory of nasalized vowels in $\mathrm{Zu}$ beroan is very restricted. I have observed that Zuberoan lacks nasalized diphthongs due to the simplification of diphthongs involving back vowels and the systematic restitution of $/ \mathrm{n} /$ after nasalized $/ \tilde{1} /$ and the nasalized front glide $/ \tilde{1} /$. I have also proposed that Zuberoan lacks nasalized mid vowels due to all instances of /e, ẽ/ being raised to /i, $\tilde{1} /$ when in a hiatus and contrastively nasalized /õ/ being systematically raised to / $\tilde{\mathrm{u}} /$, the latter raising already observed by Michelena (1977/2011). In spite of the fact that Bearnese Gascon possessed five different contrastively nasalized vowels, only loanwords involving / $\tilde{\mathbf{1}}$, $/$ have been introduced into Zuberoan. Due to the massive introduction of Bearnese loanwords involving / $\tilde{\mathbf{l}} /$ and $/ \tilde{\mathrm{u}} /$, the presence of these vowels has increased critically. In contrast, /ã/ and / $/ \tilde{y} /$ are limited to a couple of items.

In sum, this paper has discussed that, although both come from the loss of the same segment and are in contiguous dialects, the opposition of nasalized vowels is very different in the neighboring Roncalese and Zuberoan eastern Basque dialects, the distribution found in the former being more similar to that found in older stages of the western Bizkaian dialect. In spite of both distributions having nasalized vowels from the second syllable of the word - due to the loss of the nasalized aspirate $/ \tilde{\mathrm{h}} /$ - Roncalese and Bizkaian have also developed nasalized vowels in the first syllable, whereas Zuberoan maintains / $\tilde{\mathrm{h}} /$ in that domain. In addition, due to different processes, modern Zuberoan shows vowel nasality only in the stressed last syllable of the word as well as having a very restricted nasalized vowel inventory with no nasalized mid vowels and no nasalized diphthongs.

\section{ACKNOWLEDGMENTS}

This research was partially supported by the Basque Government [BFI 2010-385; GIC10/83, IT486-10]; MINECO [FFI2012-37696]; and UPV/EHU [UFI-11/14]. I am very grateful to Joseba Lakarra, Juliette Blevins, José 
Ignacio Hualde and two anonymous reviewers for their suggestions and corrections, which have undoubtedly improved the paper. All mistakes that remain in the text are mine.

\section{REFERENCES}

Arbelaiz, J. J. (1978). Las etimologías vascas en la obra de Luis Michelena. Tolosa: Kardaberaz.

Beddor, P. S. (2009). A coarticulatory path to sound change. Language, 85, 785-821. http://dx.doi.org/10.1353/lan.0.0165

Blevins, J. (2004). Evolutionary phonology: The emergence of sound patterns. Cambridge, UK: Cambridge University Press. http://dx.doi.org/10.1017/CBO9780511486357

Deen, N. G. H. (1937/1991). Glossaria duo Vasco-Islandica $(\mathrm{PhD}$ dissertation; G. Bilbao, Trans.). International Journal of Basque Linguistics and Philology [ASJU], 25, 321-426. (Reprinted from Glossaria duo vasco-islandica, 1937. Amsterdam: H. J. Paris). Retrieved from http://www.ehu.eus/ojs/index.php/ ASJU/article/view/8223

Egurtzegi, A. (2013). Phonetics and phonology. In M. MartínezAreta (Ed.), Basque and Proto-Basque. Language-internal and typological approaches to linguistic reconstruction. Mikroglottika, 5 (p. 119-172). Frankfurt am Main: Peter Lang.

Egurtzegi, A. (2014). Towards a phonetically grounded diachronic phonology of Basque ( $\mathrm{PhD}$ dissertation). Vitoria-Gasteiz: University of the Basque Country.

Egurtzegi, A. Submitted. On the phonemic status of nasalized $/ \tilde{\mathrm{h}} / \mathrm{in}$ modern Zuberoan Basque. Manuscript submitted for publication.

Egurtzegi, A., \& Elordieta, G. A history of the Basque accentual systems. Work in progress.

Gorrochategui, J. (1984). Estudio sobre la onomástica indígena de Aquitania. Bilbao: University of the Basque Country.

Hajek, J. (1993). Old French nasalization and the universals of sound change. Journal of French Language Studies, 3, 145164. http://dx.doi.org/10.1017/S0959269500001721

Hajek, J. (1997). Universals of sound change in nasalization. Oxford: Blackwell.

Hualde, J. I. (1991). Foreword to Glossaria duo Vasco-Islandica. International Journal of Basque Linguistics and Philology [ASJU], 25, 317-319. Retrieved from http://www.ehu.eus/ojs/ index.php/ASJU/article/view/8221

Hualde, J. I. (1984/1991). Icelandic Basque pidgin. International Journal of Basque Linguistics and Philology [ASJU], 25, 427437. (Reprinted from Journal of Basque Studies in America, 5, pp. 41-59) Retrieved from http://www.ehu.eus/ojs/index.php/ ASJU/article/view/8225/7387

Hualde, J. I. (1993). Topics in Souletin phonology. In J. I. Hualde \& J. Ortiz de Urbina (Eds.), Generative studies in Basque linguistics (pp. 289-327). Amsterdam: John Benjamins. http://dx.doi. org/10.1075/cilt.105

Hualde, J. I. (2003). Segmental phonology. In J. I. Hualde \& J. Ortiz de Urbina (Eds.), A grammar of Basque (pp. 15-65). Berlin: Mouton de Gruyter.

Igartua, I. (2008). La aspiración de origen nasal en la evolución fonética del euskera: Un caso de rhinoglottophilia. International Journal of Basque Linguistics and Philology [ASJU], 42, 171189. Retrieved from http://www.ehu.eus/ojs/index.php/ASJU/ article/view/2305

Ladefoged, P., \& Maddieson, I. (1996). The sounds of the world's languages. Oxford: Blackwell.

Lafon, R. (1958/1999). Contribution à l'étude phonologique du parler basque de Larrau (Haute-Soule). In J. Haritschelhar \& P. Charritton (Eds.), Vasconiana. Iker 11 (pp. 113-133). Bilbao: Euskaltzaindia. (Reprinted from D. Catalán [Ed.], Estructuralismo e historia. Miscelánea homenaje a André Martinet [Vol. 2, pp. 77-106], La Laguna: Universidad de La Laguna.)

Lakarra, J. A. (1996). Refranes y sentencias (1596). Ikerketak eta edizioa. Bilbao: Euskaltzaindia.
Larrasquet, J. (1939). Le Basque de la Basse-Soule orientale. Paris: Klincksieck.

Maddieson, I. (1984). Patterns of sounds. New York: Cambridge University Press. http://dx.doi.org/10.1017/CBO9780511753459

Martínez-Areta, M. (2009). The category of number in Basque: I. Synchronic and historical aspects. Fontes Linguae Vasconum, 110, 63-98.

Michelena, L. (1950/2011). De fonética vasca. La aspiración intervocálica. In J. A. Lakarra \& Í. Ruiz Arzalluz (Eds.), Luis Michelena. Obras completas (Vol. 7, pp. 3-20). Donostia-San Sebastián, Vitoria-Gasteiz: Diputación Foral de Guipúzcoa, University of the Basque Country. (Reprinted from Boletin de la Real Sociedad Vascongada de los Amigos del País, 6, pp. 443-459)

Michelena, L. (1953/2011). Contribución al conocimiento del dialecto roncalés. In J. A. Lakarra \& Í. Ruiz Arzalluz (Eds.), Luis Michelena. Obras completas (Vol. 6, pp. 571-608). DonostiaSan Sebastián, Vitoria-Gasteiz: Diputación Foral de Guipúzcoa, University of the Basque Country. (Reprinted from Boletin de la Real Sociedad Vascongada de los Amigos del País, 9, pp. 499-536)

Michelena, L. (1954/2011). La posición fonética del dialecto vasco del Roncal. In J. A. Lakarra \& Í. Ruiz Arzalluz (Eds.), Luis Michelena. Obras completas (Vol. 7, pp. 661-647). Donostia-San Sebastián, Vitoria-Gasteiz: Diputación Foral de Guipúzcoa, University of the Basque Country. (Reprinted from Via Domitia, 1, pp. 123-157)

Michelena, L. (1964/2011). Textos arcaicos vascos. In J. A. Lakarra \& Í. Ruiz Arzalluz (Eds.), Luis Michelena. Obras completas (Vol. 12, pp. 1-179). Donostia-San Sebastián, Vitoria-Gasteiz: Diputación Foral de Guipúzcoa, University of the Basque Country. (Reprinted from Textos arcaicos vascos, Madrid: Minotauro)

Michelena, L. (1977/2011). Fonética histórica vasca (Publicaciones del Seminario “Julio de Urquijo”). In J. A. Lakarra \& Í. Ruiz Arzalluz (Eds.), Luis Michelena. Obras completas (Vol. 6). Donostia-San Sebastián, Vitoria-Gasteiz: Diputación Foral de Guipúzcoa, University of the Basque Country. (Reprinted from Fonética histórica vasca [Publicaciones del Seminario "Julio de Urquijo”'], 2nd. ed., Donostia-San Sebastián: Diputación Foral de Guipúzcoa)

Michelena, L. \& Sarasola, I. (1987-2005). Orotariko Euskal hiztegia [General Basque dictionary] (16 Vols.). Bilbao: Euskaltzaindia. Retrieved from http://www.euskaltzaindia.net/oeh/

Ohala, J. J. (1981). The listener as a source of sound change. In C. Masek, R. A. Hendrick, \& M. F. Miller (Eds.), Papers from the Parasession on Language and Behavior (pp. 178-203). Chicago, IL: Chicago Linguistic Society.

Ohala, J. J. (1989). Sound change is drawn from a pool of synchronic variation. In L. E. Breivik \& E. H. Jahr (Eds.), Language change: Contributions to the study of its causes (pp. 173-198). Berlin: Mouton de Gruyter. http://dx.doi.org/10.1515/9783110853063.173

Ohala, J. J. (1993). The phonetics of sound change. In C. Jones (Ed.), Historical linguistics: Problems and perspectives (pp. 237-278). London: Longman.

Salaberri, P. (2013). "Apellidos Vascos" eta Mitxelenaren onomastika lanak. In R. Gómez, J. Gorrochategui, J. A. Lakarra, \& C. Mounole (Eds.), 3rd Conference of the Luis Michelena Chair (pp. 673-697). Vitoria-Gasteiz: University of the Basque Country.

Sampson, R. (1999). Nasal vowel evolution in Romance. Oxford, UK: Oxford University Press.

Trask, R. L. (1997). The history of Basque. London: Routledge.

Ulibarri, K. (2015). Dotrinazko Sermoitegia: Galduriko hizkerak eta dialektologia historikoa. ( $\mathrm{PhD}$ dissertation). University of the Basque Country.

Webster, W. (1881). The early Basque vocabulary [A letter from L. L. Bonaparte]. Revue de Linguistique et de Philologie Comparée, 14, 125-126.

Zuazo, K. (2008). Euskalkiak. Euskararen dialektoak. DonostiaSan Sebastián: Elkar. 